\title{
Alternative Sternal Closure Methods in Patients with Dehisced Sternum: Pros and Cons of Sternal Talon and Titanium Sternal Plate Fixation
}

\section{Sternum Ayrışması Gelişen Hastalarda Alternatif Kapama Yöntemleri: Sternal Kelepçe ve Titanyum Sternal Plak Fiksasyon Yöntemlerinin Artıları, Eksileri}

Omer Tanyeli

Necmettin Erbakan University, Meram Faculty of Medicine, Department of Cardiovascular Surgery, Konya, Turkey

Geliş Tarihi/Received: 11 January 2019 Kabul Tarihi/Accepted: 24 February 2019

Address correspondence to: Omer Tanyeli, Necmettin Erbakan University, Meram Faculty of Medicine, Department of Cardiovascular Surgery, 42080, Meram/ Konya, Turkey e-mail: otanyeli@gmail.com

\section{ORCID}

Omer Tanyeli

https://orcid.org/0000-0001-6275-7744

\section{Öz}

Amaç: Sternal ayrışma, kalp cerrahisi sonrasında en sıkıntılı komplikasyonlardan birisidir. Her ne kadar sternal ayrışma erken dönemde fark edildiğinde basit yöntemlerle tedavi edilebilse de, tedavidek başarısızlık veya gecikme, oldukça ölümcül olan mediastinit ile sonuçlanabilir. Bu çalışmada, başta sternal kelepçe ve titanyum sternal plaklar olmak üzere, alternatif sternum kapama yöntemlerinin özellikleri incelenmiştir.

Hastalar ve Yöntem: Çalışmaya Nisan 2015 ve Ocak 2018 tarihleri arasında, herhangi bir nedenden dolayı açık kalp cerrahisi sonrasında sternum ayrışması gelişen hastalar dahil edilmiştir. Hastalar demografik özellikleri, sternal ayrışma için risk faktörleri, operasyon tipleri ve özellikle sternal kelepçe ve titanyum sternal plakla olmak üzere sternum stabilizasyon yöntemleri açısından retrospektif olarak incelenmiştir. Bulgular: Toplamda 45 hasta sternal ayrışma nedeni ile cerrahi stabilizasyon ameliyatına alındı. Otuz dört (\%75.6) hasta erkek, $11(\% 24.4)$ hasta kadındı. İlk operasyondan sternum ayrışması gelissene kadar geçen ortalama süre 68.5 gündü (1-780 gün). Ortalama vücut-kitle indeksi $31.52 \mathrm{~kg} / \mathrm{m}^{2}(22.03-43.69 \mathrm{~kg} /$ $\mathrm{m}^{2}$ ) olarak bulundu. Sternal fiksasyon öncesi ortalama CRP değeri 68.34 iken, taburculuk öncesi 75.55 di. Eşlik eden risk faktörleri koroner arter hastalığı için internal mammaryan arter (IMA) çıkartılması, diabetes mellitus (DM), astım, kronik obstruktif akciğer hastalığı ve ileri yaş olarak tespit edildi. Ortalama post-operatif yoğun bakım kalış süresi 5.02 gün (1-29gün) iken, hastanede yatış süresi 17.18 gün (274 gün) olarak bulundu. Uç hastada (\%6.67) erken dönemde mortalite gözlendi. Operasyonda ilk tercih edilen yöntem basit kapama ve/veya Robicsek yöntemi iken, 24 hastada (\%53.3) sternal kelepçe ve/ veya titanyum plak yöntemleri kullanıldı. DM hem hastane, hem yoğun bakım kalış süreleri ile operasyon sonrası toplam yatış sürelerini artırmaktadır. DM, aynı zamanda yüzeyel ve derin sternal enfeksiyon gelişme riskini artırmaktadır $(p<0.05)$

Sonuç: Ideal sternal kapama tekniği sternumu stabilize ederken, maliyet-etkin olmalı, minimum postoperatif komplikasyonlarla birlikte en kısa hastanede yatış süresini sağlamalıdır. Sağlam interkostal aralığı olan hastalarda sternal kelepçe, genellikle sıkı yapışıklıkların neden olduğu kardiyak rüptür gibi ciddi komplikasyonların elimine edilmesini sağlar. Sternal plaklar, özellikle stabil interkostal aralıklar olmayan parçalı kırıklarda oldukça etkilidir. Bütün hastalar, sternumdaki lezyonların ve kırıkların tiplerine göre değerlendirilerek tedavi edilmelidirler.

Anahtar Kelimeler: Sternal ayrışma, kalp cerrahisi, Robicsek, sternal kelepçe, titanyum sternal plak Abstract

Aim: Sternal dehiscence is one of the most troublesome complications following cardiac surgery. Although it can be corrected by simple methods if detected earlier, treatment failure or delay in sternal dehiscence may result in mediastinitis, which is highly lethal. In this study, we aimed to investigate alternative sterna closure systems, mainly sternal talon (STalon) and titanium sternal plates (SPlate).

Patients and Methods: In between April 2015 and January 2018, patients with sternal dehiscence after cardiac surgery for any reason, were included in this study. These patients were retrospectively evaluated according to their demographic data, risk factors for sternal dehiscence, type of operations, techniques used for fixation of the sternum, mainly focusing on the STalon and titanium SPlate fixation.

Results: A total of 45 patients were taken into surgical correction because of sternal dehiscence. Thirtyfour $(75.6 \%)$ of the patients male, whereas $11(24.4 \%)$ were female. The mean time interval after the first operation to sternal dehiscence was 68.5 days (1-780 days). Mean body-mass-index (BMI) was $31.52 \mathrm{~kg} /$ $\mathrm{m}^{2}\left(22.03-43.69 \mathrm{~kg} / \mathrm{m}^{2}\right)$. Before the sternal fixation, mean CRP value was 68.34 , whereas it was 75.55 before discharge. Confounding risk factors were internal mammarian artery (IMA) harvesting for coronary artery disease, diabetes mellitus, bronchial asthma, chronic pulmonary artery disease, and advanced age Mean post-operative intensive care unit (ICU) length-of-stay (LOS) was 5.02 days (1-29 days), whereas hospital LOS was 17.18 days (2-74 days). Early mortality was observed in 3 patients $(6.67 \%)$. The first choice of operation was simple closure and/or Robicsek closure. Apart from simple and Robicsek closure techniques, sternal talon and/or titanium plates were used in 24 patients $(53.3 \%)$. DM was found to be related to extended total hospital LOS, ICU LOS, and postoperative time to discharge. DM also increased the risk of both superficial and deep sternal infection rates $(p<0.05)$.

Conclusion: Ideal sternal closure should stabilize the sternum, be cost-effective and provide the shortest hospital LOS with minimal post-operative complications. In patients with intact intercostal spaces, sternal talon may eliminate serious complications, such as cardiac rupture mainly caused by dense adhesions. Sternal plates are mainly effective in fragmented fractures without stable intercostal spaces. All patients should be individualized according to the type of lesions and sternal fractures.

Key words: Sternal dehiscence, cardiac surgery, Robicsek, sternal talon, titanium sternal plate

Cite this article as: Tanyeli $O$. Alternative Sternal Closure Methods in Patients with Dehisced Sternum: Pros and Cons of Sternal Talon and Titanium Sternal Plate Fixation. Selcuk Med J 2019;35(2): 99-104
Disclosure: Author has not a financial interest in any of the products, devices, or drugs mentioned in this article. The research was not sponsored by an outside organization. Author has agreed to allow full access to the primary data and to allow the journal to review the data if requested. 


\section{INTRODUCTION}

Median sternotomy is the most common route for cardiac operations, such as coronary bypass, cardiac valve replacement, and other open heart surgical procedures. Sternotomy starts with the separation of superficial soft tissues, followed by the electrical saw. After retracting the sternum and performing the cardiac surgery, sternum is re-approximated by sternal wires, in usual fashion. Although sternum is a rigid plate and stays far from mobility, sometimes approximation of the sternum may fail. Major sternal complications such as dehiscence, mediastinitis, osteomyelitis, sternal wound infection (SWI), and/or non-union/ displacement are infrequent after cardiac surgery (1). Though these complications are not common (0.5$2.5 \%$ ), the related mortality is unfortunately rather high, ranging between $10-40 \%$ (2). Post-sternotomy mediastinitis also leads to a dramatic increase in hospital LOS and overall hospital costs.

The treatment of sternal dehiscence and mediastinitis has evolved over the years with significant improvements in postoperative care and advancements of operative techniques. Despite the different techniques and materials described, there is no singular strategy for the management of mediastinitis with sternal dehiscence after open heart surgery (3).

In this study, we present our series of patients undergoing sternal re-approximation/re-construction specifically in the setting of sternal dehiscence after open cardiac surgery, mainly focusing on patient evaluation, decision-making on sternal closure by alternative methods including STalon and SPlate with screws, with pre-defined standard techniques.

\section{PATIENTS AND METHODS}

A total of 45 patients who had sternal dehiscence after any kind of cardiac operations between April 2015 and January 2018 were evaluated retrospectively evaluated in this study. The study protocol was approved by our faculty's Local Ethics Committee. A written informed consent was obtained from each patient before restabilization of the sternum. The study was conducted by the principles of the Declaration of Helsinki. The patients' demographic data such as age, gender, comorbid diseases were retrospectively collected from the registries. Type of the operations and materials used for sternal stabilization was classified. Patients' time interval from hospitalization until discharge and, pre and post operative infection markers were analyzed.
Each patient was taken into operation by endotracheal general anesthesia. Before the operation, each patient was given $2 \mathrm{~g}$ of Cefazoline sodium (iv) during the induction of anesthesia. Patients with known allergy/sensitivity to Cefazoline/ penicillin were given $1 \mathrm{~g}$ of Vancomycine (iv). Patients with skin lesions such as typical cellulitis/erysipelas over the sternum without isolated purulent discharge were classified as superficial sternal wound infection (SSWI) group, whereas patients with purulent discharge from the skin with accompanying diseases such as mediastinitis, osteomyelitis, or retrosternal abscess, were classified as deep sternal wound infection (DSWI) group. After performing skin incision over the pre-performed sternotomy, necrotic osseous structures and necrotic tissue remnants were debrided. Tissue specimens were obtained for microbiological cultivation from all patients. The mediastinal cavity was washed with warm saline and rifamycin solution in patients with the opened sternum. After replacing the chest tube and/or pneumatic hemovac drains, sternum was re-approximated after evaluation of the sternum and intercostals space. Patients' sterna were reconstructed either by simple sternal wire (SSWire), or Robicsek Technique (RT), or by different techniques and materials including sternal cable (SCable), sternal talon (STalon) or titanium plate (TPlate) with different shapes and screws, either alone or in combination. After the operation, all patients were taken into ICU for further medication and follow up.

All aforementioned data obtained from the patients were analyzed uploaded on the computer, and statistical analysis was performed using the SPSS for Windows version 15.0 (SPSS Inc., Chicago, IL, USA). Descriptive data was expressed in mean \pm standard deviation (SD) and median values with minimum and maximum. Categoric variables were expressed as frequencies and proportions. Continuous variables were tested for normal distribution by KolmogorovSmirnov and Shapiro-Wilk test. A $p$ value of $<0.05$ was considered statistically significant. Wilcoxon test was used for determining the relation of numeric variables, whereas Chi-square test and, Phi and Cramer V correlations were used for determining the relation of categorical data. Relation between the categorical and numeric data was evaluated by Point Biserial Correlation. For evaluation of the correlation coefficients, values between 0.00-0.19 was regarded as unrelated, 0.20-0.39 as poorly related, 0.40-0.69 as moderately related, $0.70-0.89$ as strongly related and, $0.90-1.00$ as very strongly related. 


\section{RESULTS}

Overall, $34(75.6 \%)$ of the patients were male, and 11 (24.4) of the patients were female. Mean age of the patients was $67.49 \pm 9.23$ years, with median 68 (min:47, max:84) years. Mean BMI was $31.52 \mathrm{~kg} / \mathrm{m}^{2}$ (22.03-43.69 kg/m²) with median 30.85 (min:22.03, max:43.69). Twenty-nine (64.4\%) of the patients were active smokers with smoking habit of $49.07 \pm 15.59$ pack-years (median 50, min:20, max:80). Twentyfour $(53.3 \%)$ of the patients had diabetes mellitus, 10 $(22.2 \%)$ had bronchial asthma, $14(31.1 \%)$ had chronic obstructive pulmonary disease, as confounding chronic diseases. Twenty-two $(48.9 \%)$ of the patients had single and, $13(28.9 \%)$ patients had more than one chronic diseases, whereas $10(22.2 \%)$ had none. IMA was harvested from $37(82.2 \%)$ of the patients during the first operation. Thirty-four $(75.6 \%)$ of the patients previously had coronary artery bypass graft (CABG) surgery, 6 (13.3\%) had non-CABG surgery, and $5(11.1 \%)$ had any other cardiac operations (e.g. valvular) in combination with CABG surgery (Figure 1).

In $26(57.8 \%)$ of the patients, one single method was enough for fixation/reconstruction of the sternum, whereas 16 (35.6\%) needed two, and $3(6.7 \%)$ patients needed three methods in combination. The most common method used in sternal closure techniques was RT $(66.7 \%)$, whereas the least one was SCable (6.7\%). STalon was used in 21 (46.7\%) patients, either alone, or in combination. The most twocombined methods were RT and STalon techniques, used in $9(20 \%)$ patients. In $8(17.8 \%)$ of the patients, STalon was enough for sternal closure, without resternotomy. TPlate was used in $6(13.4 \%)$ patients, in combination with either RT, or STalon. Apart from STalon, TPlate was not used as single technique in the afore-mentioned patients. The most common

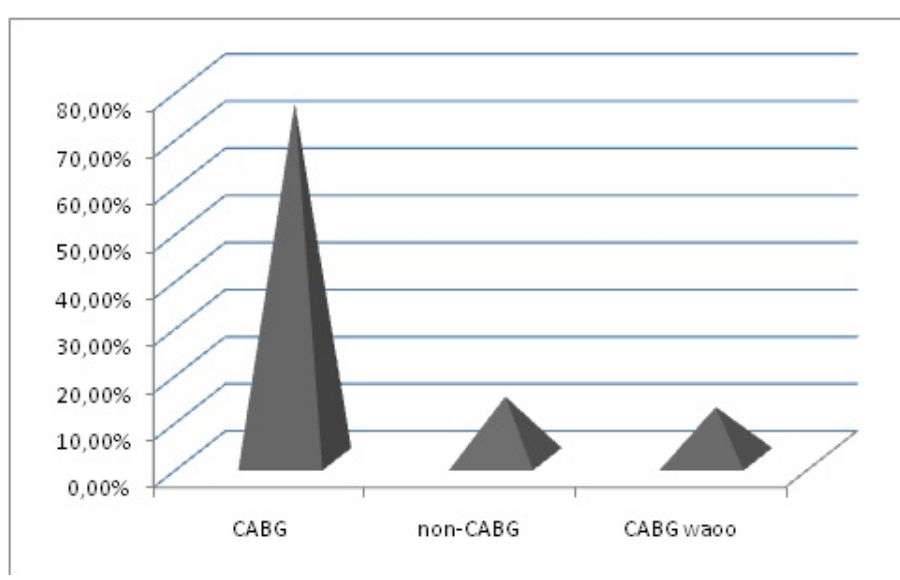

Figure 1. Type of the operations associated with sternal dehiscence (CABG: coronary artery bypass graft; waoo: with any other operations)

single closure technique was RT, without any need for extra supportive material (13 patients, $28.9 \%$ ).

Among the patients with sternal dehiscence, 8 $(17.8 \%)$ had DSWI, whereas $18(40 \%)$ had SSWI. Forty-two $(93.3 \%)$ of the patients were discharged after completion of their medication, whereas exitus was observed in $3(6.7 \%)$ patients. All patients who developed exitus had diabetes, with dehiscence related mediastinitis, and had DSWI with positive Acinetobacter Baumanii cultivation, resistant to antibiotherapy. Some of the data of the patients operated for sternal dehiscence are presented in Table 1. The number of methods used for sternal fixation had no correlation with gender, presence of chronic diseases, use of IMA or smoking habit, when evaluated with Chi-square test $(p>0.05)$. Presence of DSWI had no correlation with gender, presence of chronic diseases or smoking habit, when evaluated with Chi-square test $(p>0.05)$. DSWI and BMI had no

Table 1. Data of the patients operated for sternal dehiscence (ICU: Intensive care unit; LOS: Length of stay; CRP: C-reactive protein; WBC: White blood cell count)

\begin{tabular}{|c|c|c|c|c|c|c|c|c|}
\hline & $\begin{array}{l}\text { Dehiscence } \\
\text { time after } \\
\text { the first } \\
\text { operation } \\
\text { (Day) }\end{array}$ & $\begin{array}{l}\text { Total } \\
\text { hospital } \\
\text { LOS } \\
\text { (Day) }\end{array}$ & $\begin{array}{l}\text { Total } \\
\text { ICU } \\
\text { LOS } \\
\text { (Day) }\end{array}$ & $\begin{array}{l}\text { Hospitalization } \\
\text { CRP } \\
(\mathrm{mg} / \mathrm{L})\end{array}$ & $\begin{array}{l}\text { Discharge } \\
\text { CRP } \\
(\mathrm{mg} / \mathrm{L})\end{array}$ & $\begin{array}{l}\text { Initial } \\
\text { WBC } \\
\left(/ \mathrm{mm}^{3}\right)\end{array}$ & $\begin{array}{l}\text { Discharge } \\
\text { WBC } \\
\left(/ \mathrm{mm}^{3}\right) \\
\text { operation }\end{array}$ & $\begin{array}{l}\text { Time to } \\
\text { ischarge } \\
\text { after sternal } \\
\text { (Day) }\end{array}$ \\
\hline Mean & 68,53 & 17,18 & 5,02 & 68,34 & 75,55 & 12525,56 & 11185,56 & 8,52 \\
\hline $\begin{array}{l}\text { Standaro } \\
\text { deviation }\end{array}$ & 143,15 & 14,10 & 4,42 & 61,60 & 51,56 & 8979,92 & 11925,03 & 5,86 \\
\hline Median & 21 & 14 & 4 & 50,30 & 69,10 & 10000 & 8980 & 6,50 \\
\hline Minimum & n 1 & 2 & 1 & 2 & 3,5 & 5800 & 3400 & 3 \\
\hline Maximun & m 780 & 74 & 29 & 222 & 258,9 & 64300 & 86400 & 35 \\
\hline
\end{tabular}


Table 2. Values related to point biserial correlation coefficient. (DM; Diabetes Mellitus; DSWI: Deep sternal wound infection; ICU: Intensive care unit; LOS: Length-ofstay; SSWI: Superficial sternal wound infection).

\begin{tabular}{llll}
\hline Variables & $\begin{array}{l}\text { Total } \\
\text { hospital } \\
\text { LOS }\end{array}$ & $\begin{array}{l}\text { Total } \\
\text { ICU } \\
\text { LOS }\end{array}$ & $\begin{array}{l}\text { Postoperative } \\
\text { time to } \\
\text { discharge }\end{array}$ \\
\hline DM & 0,685 & 0,467 & 0,551 \\
DSWI & 0,715 & 0,591 & 0,840 \\
SSWI & 0,682 & 0,469 & 0,609 \\
\hline
\end{tabular}

correlation when examined by point biserial correlation (Eta:0.159). There were also statistically no difference between the hospitalization and discharge CRP and WBC values, when examined by Wilcoxon test $(p>0.05)$. There was a moderate correlation between presence of DM and total hospital length of stay (LOS) $(E t a=0.685)$, total ICU LOS (Eta=0.467), and postoperative time to discharge $(E t a=0.551)$. There was a strong correlation between DSWI and total hospital LOS (Eta=0.715), moderate correlation with total ICU LOS (Eta=0.591), and strong correlation with postoperative time to discharge $(\mathrm{Eta}=0.840)$. There was a moderate correlation between SSWI and total hospital LOS (Eta=0.682), total ICU LOS (Eta=0.469), and postoperative time to discharge (Eta=0.609). Values related to point biserial correlation coefficient are shown in Table 2.

When the relation between DM and DSWI was evaluated by Phi and Cramer V correlation, a positive significant relation was detected $(P h i=0.318 ; p=0.033)$. When the relation between DM and SSWI was evaluated by Chi-square test, there was a statistically meaningful difference $(x 2=7.202 ; p=0.007)$.

\section{DISCUSSION}

The present study indicates that fixation of the sternum using STalon and Splate with different shapes and screws either alone, or in combination with standard SSWire or RT techniques, is an effective management strategy to recover a severely dehisced sternum, providing thoracic wall stability. Median sternotomy for open cardiac surgical procedures is a bone splitting procedure with quick and easy performance, excellent access to heart and great vessels. Sometimes it can be complicated by poor healing, resulting in sternal dehiscence at an incidence of $0.5-5 \%$ with or without infection (4). Patients with higher risk group for sternal dehiscence are those with obesity, osteoporosis, chronic obstructive pulmonary disease, DM and patients on long-term immunosuppressive drugs (4).

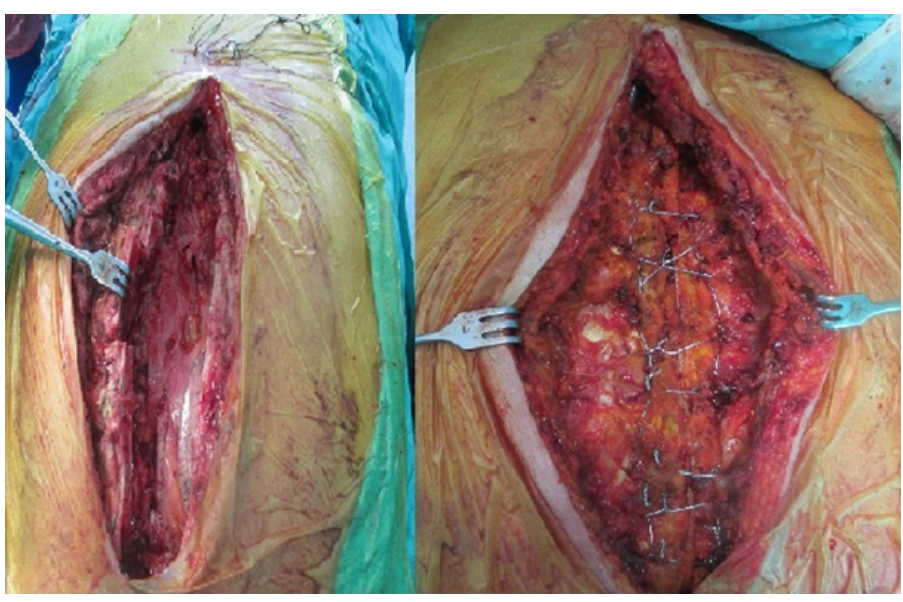

Figure 2. Closure of the dehisced sternum with Robicsek technique.

The surgical technique also contributes in particular to off midline sternotomy and weak closure technique (5). In our series of patients, major leading causes of sternal dehiscence were advanced age, obesity, IMA use for CABG surgery and DM. DM was also found to be associated with DSWI, leading to increased both ICU LOS and overall hospitalization period. In order to solve the fixation problems in a dehisced sternum, various techniques have been described in the literature, RT being the most popular and widely used one, which was first described by Robicsek in 1977. In this technique, bilateral and longitudinal parasternal steel wires are placed before application of horizontal steel wires (6). In our series of patients, the most common single closure technique was also RT (Figure 2), without any need for extra supportive material (13 patients, 28.9\%). This procedure has several advantages: it stabilizes the sternum if it is fragile or broken, or if subsequent instability develops, it prevents the wires cutting through the bone, it changes the site of pressure and provides wider support (7). The disadvantage lies beneath the disruption of the collateral blood supply of the sternum and effective approximation of the top and bottom of a gaping sternum cannot be obtained (6). Low cost and no need for additional materials are other advantageous factors. Patients may still experience complete or partial symptomatic nonunion secondary to poor osteosynthesis with traditional metal wires.

Sternal fixation with rigid techniques has been reported be both promising and lifesaving (8). STalon is one of the rigid fixation systems used for approximation of the sternum, available in the 


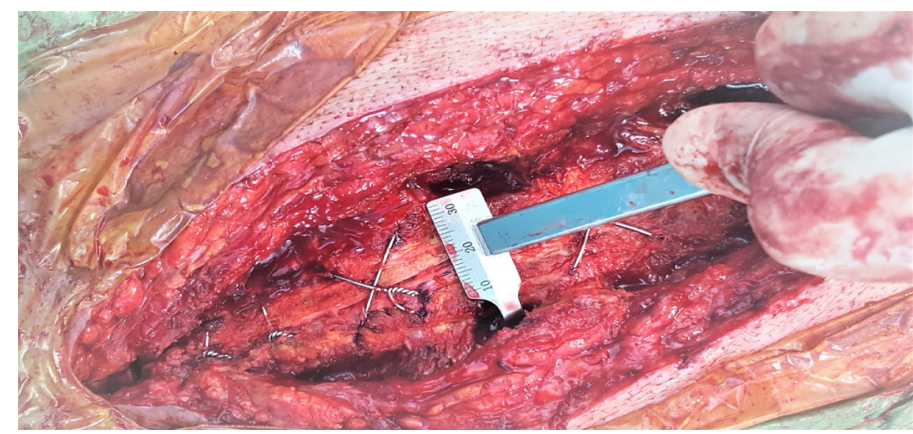

Figure 3. After measuring the size of the width of the sternum, usually one size less of STalon helps better approximation of the sternum

market. Probably, the most important factor is the correct evaluation of the patient's sternum including intercostal spaces. If the patient has intact intercostal spaces, without segmental fractures of the sternum, such as caused by broken and/or loose sternal wires, STalon has the advantage of avoiding re-opening of the mediastinal cavity. Since most of the dehisced sternal cases are operated in the very first few weeks of the primary operation where there is dense adhesions, this technique avoids direct contact of the mediastinal cavity, in a way a re-do operation. In such cases, the patient should be free of DSWI. Sternal bone and borders should be debrided for better bone healing, intercostals spaces should be freed for placement of the STalon. After measuring the size of the width of the sternum, usually one size less of STalon helps better approximation of the sternum (Figure 3). The sternum is approximated by the help of an approximator, and the screw is locked (Figure 4 ). The ease of placement could be a key factor in routine use of this device. It provides good horizontal support, decreases pressure over the sternal wires and does not alter sternal collateral blood supply, as in the standard RT. It also avoids screws (no drilling required), allowing low complication rates (9). STalon is not effective if the intercostal spaces are torn by pre-admitted sternal wires. If the patient has poor subcutaneous tissue or convex sternum, it may irritate the skin tissue, leading to secondary wound constitution. In our series, we had to remove one of the STalon devices after 3 months, as a result of secondary irritation of the skin. It also provides extra cost to healthcare budget.

TPlate fixation is another rigid fixation method, used for stabilization of dehisced sternum. Up to now, several cardiac centers described their experiences with titanium SPlate fixation systems (10). Rigid sternal fixation is a replication of principles learned from bone stabilization in other parts of the body (11). It provides a high sternal stability rate at hospital discharge. It was found to be superior in stabilizing the sternal bone when compared with conventional refixation methods, especially in secondary closure after poststernotomy mediastinitis (10). This material is suitable especially in patients with fractured and torn sternum, without intact intercostals space. After approximation of the sternum, it also provides vertical and horizontal support to the sternum by the aid of screws attached to the ribs and sternal bony structure. It has the advantage of combination with standard RT and SSWire techniques. The material has different shapes and figures in the market, with different sizes of screws. Main disadvantage is its potential of lung and bone injury, by vertically drilled screws, leading to additional bone damage/fractures. Because of its rigid nature, it may need additional reshaping according to the convexity of the sternum and ribs. As in STalon procedures, it may cause skin irritation, especially in patients with weak subcutaneous structures. In our series of patients, TPlate was used in $6(13.4 \%)$ patients, in combination with either RT, or STalon (Figure 5). Only one patient needed removal

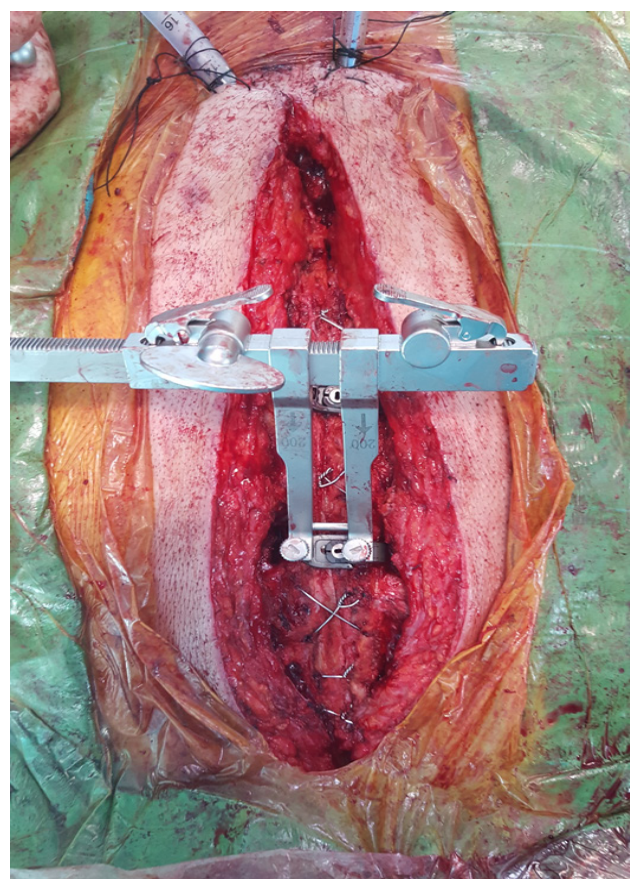

Figure 4. The sternum is approximated by the help of an approximator, and the screw is locked. 


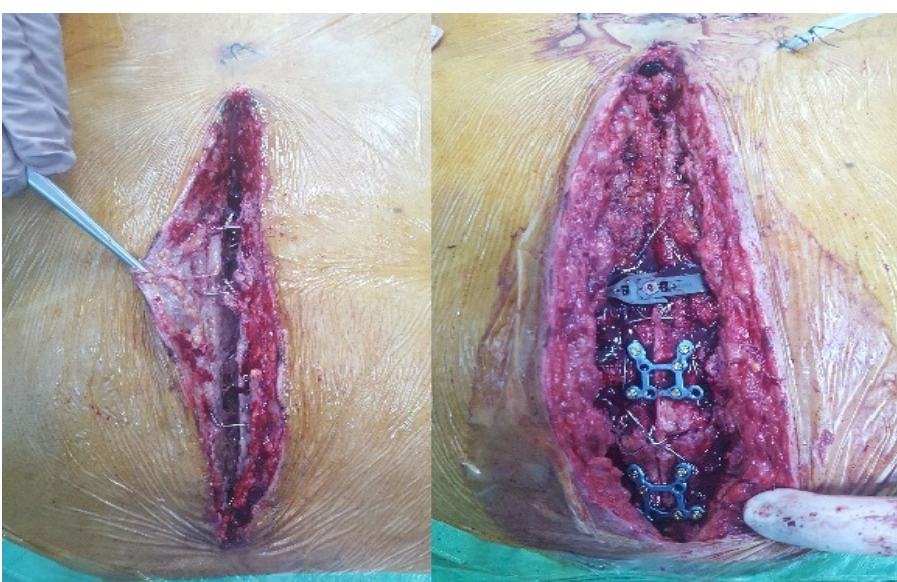

Figure 5. Combination treatment of dehisced sternum with sternal talon, titanium sternal plate and Robicsek technique.

of the material after 45 days, as a result of secondary irritation.

None of the aforementioned materials fit for all patients with sternal dehiscence. The problem of each patient should be individualized, and patientbased solutions should be obtained by confirming structural deformity of the sternum, integrity of the intercostals space and presence of the underlying DSWI. In cases with DSWI, application of vacuumassisted systems may also improve infectious burden or application extra barriers (e.g. pectoralis or rectus abdominis muscle flaps) may improve healing. Patients with DM and osteoporosis should be carefully evaluated for IMA harvesting during CABG surgery for better sternal healing. In order to improve wound healing and reduce tension over the skin, supportive prolene sutures with nylon packages may be applied, especially in obese patients (12). A major limitation of this study is its retrospective design with relatively small size of the groups. The patients reflect a single center experience. A larger group of patients are warranted for multi-center experiences in a prospectively designed study.

\section{CONCLUSION}

Ideal sternal closure should stabilize the sternum, be cost-effective and provide shortest hospital LOS with minimal post-operative complications. In patients with intact intercostal spaces STalon, a new alternative sternal closure system, may eliminate serious complications, such as cardiac rupture mainly caused by dense adhesions. Our study proved that STalon is safe to use, easy to apply in a non time consuming way, with low complication rates. SPlates are mainly effective in fragmented fractures without stable intercostal spaces. All patients should be individualized according to type of lesions and sternal fractures.

Conflict of interest: Author declares that there is no conflict of interest between the authors of the article.

Financial conflict of interest: Author declares that he did not receive any financial support in this study.

Address correspondence to: Omer Tanyeli, Necmettin Erbakan University, Meram Faculty of Medicine, Department of Cardiovascular Surgery, Konya, Turkey.

Phone:+90 (332) 2236861 Mobile: +90 (532) 7678909

e-mail: otanyeli@gmail.com

\section{REFERENCES}

1. Fedak PW, Kolb E, Borsato G, et al. Kryptogenic bone cement prevents pathologic sternal displacement. Ann Thorac Surg 2010;90:979-85.

2. Casha AR, Yang L, Kay PH, et al. A biomechanical study of median sternotomy closure techniques. Eur J Cardiothorac Surg 1999;15:365-9.

3. Chang El, Festekjian JH, Miller TA, et al. Chest wall reconstruction for sternal dehiscence after open heart surgery. Ann Plast Surg 2013;71:84-7.

4. Losanoff JE, Richman BW, Jones JW. Disruption and infection of median sternotomy: a comprehensive review. Eur J Cardiothorac Surg 2002;21:831-9.

5. Subramaniam T, Keita L, Veerasingam D. Sternal Talon, a novel repair for sternal dehiscence. Kardiochir Torakochirurgia Pol 2015;12:153-4.

6. Robicsek F, Fokin A, Cock J, et al. Sternal instability after midline sternotomy. Thorac Cardiov Surg 2000;48:1-8.

7. Schimmer C, Sommer SP, Bensh M, et al. Sternal closure techniques and postoperative sternal wound complications in elderly patients. Eur J Cardiothorac Surg 2008;34:132-8.

8. Song DH, Lohman RF, Renucci JD, et al. Primary sternal plating in high risk patients prevents mediastinitis. Eur $\mathrm{J}$ Cardiothorac Surg 2004;26:367-72.

9. DeLong MR, Hughes DB, Gaca JG, et al. Sternal talon offers a solution for secondary sternum osteosynthesis in patients with nonunion. Ann Thorac Surg 2014;98:1804-8.

10. Vos RJ, Jongbloed L, Sonker U, et al. Titanium plate fixation versus conventional closure for sternal dehiscence after cardiac surgery. Thorac Cardiovasc Surg 2017;65:338-42.

11. Elghonemy YF, Hussein MA. Titanium plate fixation versus wire sternal closure in coronary artery bypass graft patients: Need for rigid sternal fixation. J Egypt Soc Cardio-Thor Surg 2016;24:150-8.

12. Orhan A, Ozergin U. A new technique for sternal wound closure in obese patients undergoing open heart surgery. Turk Gogus Kalp Dama 2013;21:864-5. 